\title{
The Role of Woman Entrepreneurship in Creative Tourism Development
}

\author{
Agusdin ${ }^{*}$, Santi Meitasari², \& Lalu Muhammad Furkan ${ }^{3}$
}

\author{
${ }^{1}$ University of Mataram, Mataram Indonesia \\ ${ }^{2}$ Office of Industry, Mataram Indonesia \\ ${ }^{3}$ University of Mataram, Mataram Indonesia \\ *Corresponding author. Email: agusdin@unram.ac.id
}

\begin{abstract}
This paper draws on a case of a woman entrepreneur (Zaenab) who has been innovative, establishes a business (UD Azhari), initiates the establishment of a sustainable tourism village (Green Village of Bilebante) and develops creative tourism businesses as community development. A descriptive case study research method was used, and data were collected through observation and in-depth interviews. The study reveals a journey and series of reasons why this specific entrepreneur has been innovative. An entrepreneur's key success in creating a business is implementing four principles of Sarvodaya ideology: 1) collective ownership, 2) cooperation, 3) selfreliance, and 4) profit sharing. The business creation activities were also initiated and conducted cooperatively by the members of the communities, the support of the government, and other stakeholders. The paper suggests how these findings may contribute to developing creative businesses in tourism and community development. This study also stimulates further research for sustainable community development and provides inputs for government agencies in determining policy and strategy for community development.
\end{abstract}

Keywords: Woman Entrepreneurship, Creative Tourism, Sustainable Tourism, Community Development, Sustainable Development.

\section{INTRODUCTION}

The creative economy is currently considered as one of the most rapidly growing industries of the world economy today. The creative economy is a new economy that intensifies technology, information, and creativity by relying on the idea and knowledge of its human resources as the main factor in its economic activities. So, the creative economy relies on creativity, knowledge, and information possessed by human resources as the main actor. Human creativity and innovation are the key drivers of these industries at both individual and group levels and have become the true wealth of nations in the 21st century (UNESCO and UNDP, 2013, p.15). Many scholars study creative economy and come with their concepts of "creative industries" (Hesmondhalgh, 2002, p. 12; Howkins, 2001, pp. 88-117; UNCTAD and UNDP, 2008, pp. 11-12), "cultural industries" and "creative economics" (Hesmondhalgh, 2002, pp. 11-14; UNCTAD and UNDP, 2008, p. 12). The UK Government Department for Culture, Media, and Sport (DCMS) defines and describes the creative industries as:

"those industries which have their origin in individual creativity, skill, and talent and which have a potential for wealth and job creation through the generation and exploitation of intellectual property" (Newbigin, 2010). Therefore, the DCMS definition suggests nine creative industries, namely (1) advertising and marketing; (2) architecture; (3) crafts; (4) designs: product, graphic, and fashion design; 
(5) film, TV, video, radio, and photography; (6) information technology (IT); software and computer services; (7) publishing; (8) museums, galleries, and libraries; and (9) music, performing and visual arts. This paper discusses the concept of creative tourism and tourism entrepreneurship and its application, including characteristics and profiles of women entrepreneurs and how creative tourism can contribute to developing business opportunities and entrepreneurial ventures to boost community wealth and well-being.

\section{RESEARCH METHODS}

Case studies aim to analyze specific issues within the boundaries of a specific environment, situation, or organization. An explanatory case study research method was used, and data were collected through observation and in-depth interviews. Explanatory case studies aim to answer "how' or "why" questions with little control on behalf of the researcher over events. This type of case study focuses on phenomena within the contexts of real-life situations. The essence of a case study, the central tendency among all types of case study, is that it tries to illuminate a decision or set of decisions: why they were taken, how they were implemented, and the results (Schramm, 1971). The main qualitative data were collected through in-depth interviews with women who become pioneers of entrepreneurial activities (Ibu Zaenab), other stakeholders (Head of Village and Kampung), government and private agencies, and community group members. The observation was also conducted on the businesses established and run by entrepreneurs.

\section{RESULTS AND DISCUSSIONS}

3.1 The motivations and commitments of the business founder

\subsubsection{Product and operation}

UD. Azhari is a small business situated in Bilebante village, Central Lombok, West Nusa Tenggara (WNT) Province, Indonesia. It started its operation in 2007 when the founder, Zaenab, opened a small shop selling snacks and chips for the neighborhood. Unfortunately, the business suffered from financial problem, which led to bankruptcy. This experience motivated Zaenab to develop her business knowledge and request entrepreneurial support from government institutions. In 2011, Zaenab joined a tortilla chip-making course conducted by the Indonesian Ministry of Cooperatives, Small, and Medium Enterprises, where she acquired the skills and started to focus on the tortilla chip business. Zaenab has invented a new tortilla recipe from many trials and errors where she added local ingredients in it (i.e., seaweed). The new tortilla recipe turned out to be highly favored by customers because it tastes better and healthier since it is made of natural raw material without any additive and preservative. At first, she offered her product locally around her village but with the help of GIZ, a company that specializes in international development that assists the enterprise's management and marketing, her business has grown gradually into a larger scale.

Learning from her past business experiences, she managed to make the business and the community even stronger as she involves the community in the business. After that, Zaenab started to invite women who live close to her house to work together and cooperatively produce tortilla chips. She created a model of the community-based enterprise (CBE) where the community members take part as owners, managers, and employees who act corporately to open the business opportunity and order themselves to answer the challenges (Peredo \& Chrisman, 2006).

UD. Azhari's members are women who are committed to working hard and determined to capacitate themselves. However, most women are unskilled and less educated and do not have money or experience to start a business. Therefore, Zaenab must transfer her knowledge in the tortilla chip-making process to standardize the product and maintain its quality. Every member must go through a training course before they can join the cluster. Each cluster consists of ten women with 
one cluster leader responsible for the quality control of the product, cluster's financial report, and supply chain.

All clusters have to work cooperatively to produce raw tortilla chips based on the standard required for the raw tortilla chip. Each cluster has to deliver the raw tortilla chip to UD. Azhari weekly while collecting another batch of raw materials weekly. The raw tortilla chip will enter the finishing and packing process in UD. Azhari processing center before it is distributed to the customers. Every member will be paid based on their productivity, and from this business model, each member could earn a stable income of around $\mathrm{Rp}$. 800,000 per month. Besides that, all members will receive shared profit, which will be collected from the $25 \%$ savings of the profit. UD. Azhari also hires staff who are handling several roles such as marketing, distribution, and administration.

Zaenab's achievement has attracted the government's attention as her business continues to grow. UD. Azhari now employs and has provided self-employment opportunities to approximately 300 women. These clusters are from around her village and other districts (20 clusters in Central Lombok and 10 clusters in West Lombok). In fact, Zaenab has immersed herself in various human development programs and became one of the national-level trainers in the field of maritime affairs and fisheries, known as P2MKP. She has received much support from the government, like a production equipment grant - which she distributed to all 30 cluster members and regularly participates in trade shows and exhibitions locally and nationally. Zaenab has the network to connect the communities with substantial social capital like government institutions, NGOs, banks, other business communities, as Lyons describes (as cited in Paredo \& Chrisman, 2006) is a key strategy in fostering sustainable development among poor communities.

\subsubsection{Social Issues}

UD. Azhari was primarily established for business purposes, but Zaenab' $\mathrm{s}$ initiative to involve the communities now operates as a social enterprise. In line with the definition of social entrepreneurship by Korosec and Berman (2006) (as cited in Dacin et al., 2010), where "social entrepreneurs are defined as individuals or private organization that takes the initiative to identify and address important social problems in their communities" (p.39). Another definition of social entrepreneurship that relates to Zaenab is a definition by Germak and Robinson (2014) where "social entrepreneurs are restless, mission-driven individuals that strive to change the world, their cities, and their communities by implementing sustainable business ventures designed to create social impact" (p.5). The main social motive of UD. Azhari is to alleviate poverty in the community by empowering women so that they can be financially independent.

\subsubsection{Motivation}

Reflecting the study by Germak and Robinson, Zaenab's motivations for social entrepreneurship are: 1) personal fulfillment, 2) achievement orientation, 3) helping the society, and 4) closeness to the social problem (Germak \& Robinson, 2014). From the interview, personal fulfillment is one of Zaenab's motivations to engage in social entrepreneurship. The way she expressed that she wanted to help her husband to earn more money for the family by doing business in selling snacks and chips is evident for self-actualization. Zaenab is also determined to make the whole community financially independent, especially for women who are oppressed with economic stress. As cited in Kompas, an Indonesian national newspaper, she said that "It is common for a very successful person in her business, but that would be a great achievement if we can make other people also successful" (Anwar, 2016). The government has recognized her achievement and she received the best tortilla producer award in 2014. Her background from a low-income family and the fact that she has been witnessing that many women are struggling for life and oppressed by financial problems have affected her deeply. She feels more emotionally connected and more compassionate to other people's problems. Looking at her motivation to 
help the society and her closeness to the problem as a manifestation of her compassion that blends with personal fulfillment and achievement orientation emerged as her motivational components to engage to nascent social entrepreneur (Germak \& Robinson, 2014).

\subsubsection{Commitment}

In running its business, UD. Azhari is a type of social entrepreneurship that Dorado describes (2006) (as cited in Datta \& Gaily, 2012) as a "for-profit business that defines its mission as being both social and economic" (p.572). As most of UD. Azhari' female partners lack resources, UD. Azhari has committed to 1) helping them to create a cluster until it settles, 2) providing them with production tools (from the asset of the enterprise or try to seek a grant from the government for bigger tools), 3) providing them with raw materials to make a tortilla, and 4) receive their tortilla production, consolidate, and market their products. Above all, Zaenab continuously supports all the members to increase their self-confidence, motivation, marketing, and business skills. This model encourages all the women in the cluster to produce high-quality tortilla chips and, at the same time, enables them to finish their family responsibilities.

The success of UD. Azhari, as a community-based enterprise, creates opportunities for CBEs in other communities or other fields of businesses (Peredo \& Chrisman, 2006). As mentioned earlier that the main ingredient of tortilla chips is corn and seaweed-currently, the average of the total production of UD. Azhari is $80-100 \mathrm{kgs}$ per day with only 10-13 clusters active in production; however, the founder is preparing to scale up the product so that the entire 30 clusters will actively work. This production plan requires a continuous supply of corn and seaweed. Indeed, this circumstance opens the opportunity to corn farmers around the villages as they also benefit from UD. Azhari's business. Before UD. Azhari's penetration in the market, the price of corn was constantly fluctuating, and farmers often suffered losses. Now that UD. Azhari has committed to buying corn from local producers with the agreed price, both UD.
Azhari and farmers are benefited from this arrangement. Consequently, corn farmers are more motivated to look after their land to produce good quality corn. This also applies to seaweed farmers since UD. Azhari requires good quality of seaweed materials for its production; seaweed farmers give more attention to the planting system that is more environmentally friendly.

\subsection{The Business Model}

The main focus of social entrepreneurship is to create social value, whether it is a not-forprofit or for-profit enterprise, depending on the particular business model and the social problem needed to be solved (Mair \& Marti, 2006). UD. Azhari business model is like the study by Datta and Gailey (2012) on Lijjat in India. Both of them work with the same value, which Datta and Gailey describe as the four principles of Sarvodaya ideology: 1) collective ownership, 2) cooperation, 3) selfreliance, and 4) profit sharing. Collective ownership in UD. Azhari is accounted for by "joint ownership" of the cluster assets. As mentioned earlier, all the cluster members are provided with production equipment like mini corn grinding machines, large pots, and utensils. If one cluster is not active as required by UD. Azhari, all the equipment will be transferred to another active cluster. Another fundamental value is cooperation. In the practice of collective ownership, the decisions that affect all the members are discussed togetherfor instance, the buyback price of raw tortilla chip from the cluster to UD. Azhari, the price will be agreed upon by calculating all aspects so that all parties receive benefits, and the percentage of sharing profit will also be agreed upon. The sense of belonging to the business "can foster, even require, more cooperative behavior" (Datta \& Gailey, 2012).

\subsection{The Triple Bottom Line}

The entrepreneurial journey of UD. Azhari, which was primarily established for business purposes to be more social, represents that social entrepreneurship is about a process (Mair 
\& Marti, 2006). In social entrepreneurship, Mair and Marti add that economic value creation by earning income is essential to ensure financial sustainability, while social wealth creation is still the primary goal. UD. Azhari's business model has maintained the balance of economic viability with the social and the environmental goals (Dixon \& Clifford, 2006). The balance of these three bottom lines (economy, social, and environment) is essential for corporate sustainability - the business model of UD. Azhari, as a for-profit social enterprise that offers opportunities for women to earn stable income, has a positive impact on the financial aspect of the societies.

Consequently, the welfare of society increases. With a stable income, women feel more secure about their lives, family, and future. These circumstances accommodate them to be more productive and more focus on their future. While the environmental benefit comes from the interconnected supply chain between UD. Azhari with corn and seaweed farmers. The farmers pay more attention to their land and the environment to obtain sustainable benefits from it.

Currently, Zaenab is preparing for further social development in which she prepares the youth to learn and start building a business cluster in different product categories: body care products. The objective is to provide job opportunities for the younger generation by teaching them vocational skills not to have any financial problems in the future - the idea of UD. Azhari on entrepreneurship and sustainability has been extended to the further development of the societies - as regarded as the fourth pillar of the quadruple bottom lines (Walters \& Takamura, 2015). Altogether, the success of UD. Azhari, in its developmental activities, comes from the cooperation of the members of the different communities and the convergence of government agencies and other stakeholders but not conceived and managed by the development agencies (Peredo \& Chrisman, 2006).

\subsection{Creative tourism development}

A creative tourism business is a business that focuses on providing products or services involving tourist experiences and participation as well educating them in the field of arts, heritage, culture, or unique character of a place. In addition, it should provide a connection with the community, its culture, and dayto-day life. Richards and Marques (2012) suggest that creative tourism is a form of networked tourism, which depends on the ability of producers and consumers to relate to each other and generate value from their encounters. Three levels of collaboration and partnerships could be determined, namely:

1. the co-creation of tourism experiences between local communities/residents and tourists (Binkhorst \& Den Dekker, 2009)

2. the collaboration and alliances between local stakeholders at a destination level, between citizens, artists, craftsmen, NGOs, private companies, and public organizations.

3. the networking at a global level, between creative tourism destinations that, despite their diversity, share a common objective to reach the creative tourists.

Richards and Raymond (2000) define creative tourism as tourism that offers visitors the opportunity to develop their creative potential through active participation in courses and learning experiences, characteristic of the holiday destination that the visitors visit.

\section{CONCLUSION}

A developing country like Indonesia has been fighting poverty for long periods. Poverty is a severe issue that could affect the stability of a country and, in the end, affect the whole country. Therefore, poverty needs to be overcome, and all stakeholders should work together to fight for it. The scholar suggests Community-based enterprise as one way to address poverty in a developing country. UD. Azhari arises as a for-profit community-based social enterprise that aims to alleviate poverty 
among female community members. This essay has described UD. Azhari's journey from its inception to becoming a social enterprise. The motivation and commitments of the founder to address social issues around her villages have been translated into its business model that applies the four principles of Sarvodaya ideology: 1) collective ownership, 2) cooperation, 3) self-reliance and 4) profit sharing. UD. Azhari's business model has performed the triple bottom line framework from its activities and positively impacted the social, environmental, and financial part. Moreover, the purpose of further social development by UD. Azhari's on youth entrepreneurship and sustainability is counted as the fourth pillar of the quadruple bottom line.

\section{REFERENCES}

Anwar, K. 2016. Bisnis Keripik Berjamaan. Retrieved October 10, 2016, from Kompas.com: http://print.kompas.com/baca/gayahidup/sosok/2016/06/10/Bisnis-Keripik-Berjemaah.

Dacin, P. A., Dacin, M. T., \& Matear, M. 2010. Social Entrepreneurship:Whu We Don't Need a new Theory and How We Move Forward From Here. Academic of Management Perspectives , 37-57.

Datta, P. B., \& Gailey, R. 2012. Empowering Women Through Social Entrepreneurship: Case Study of Women's Cooperative in India. Entrepreneurship Theory and Practice, 36(3): 569-587.

Dixon, S. F., \& Clifford, A. 2006. Ecopreneurship - A New Approach To Managing The Triple Bottom Line. Journal of Organizational Change Management, 20(3): 326-345.

Binkhorst, E., \& Dekker, T.D. 2009. Agenda for CoCreation Tourism Experience Research, Journal of Hospitality Marketing \& Management, 18(2-3): 311-327, DOI: 10.1080/19368620802594193

Germak, A. J., \& Robinson, J. A. 2014. Exploring the Motivation of Nascent Social Entrepreneurs. Journal of Social Entrepreneurship , 5(1): 5-21.

Hesmondhalgh, D. 2002. The Cultural Industries London. Pp 12, SAGE Publication Ltd.

Howkins, J. 2001. The Creative Economy: How People Make Money from Ideas. Pp 88-117. Allen Lane Publisher.

Mair, J., \& Marti, I. 2006. Social Entrepreneurship Research: A Source of Explanation, Prediction, and Delight. journal of World Business, 4(1): 36-44.

Newbigin, J. 2010. The creative economy: an introductory guide, pp.17. British Council.
Peredo, A. M., \& Chrisman, J. J. 2006. Toward A Theory of Community-Based Enterprise. Academic of Management Review, 31(2): 309-328.

Poverties. (2015, October 5). Causes \& Effects of Poverty on Society, Children and Violence. Retrieved October 12, 2016, from Poverties: http://www.poverties.org/blog/effects-of-poverty

Richards, G. and Marques, L.2012. Exploring Creative Tourism: Editors Introduction, Journal of Tourism Consumption and Practice, 4(2): 1-11.

Richards, G. and Raymond, C. 2000. Creative tourism. ATLAS news no 23, pp 16-20, ISSN1388-3607

Schramm, W. 1971. The Process and Effects of Mass Communication (Rev. ed.). Urbana, IL: University of Illinois Press.

United Nations. 2008. Creative economy report 2008, pp. 11-12. United Nations.

https://unctad.org/system/files/officialdocument/ditc20082cer_en.pdf.

Walters, F., \& Takamura, J. (2015). The Decolonized Quadruple Bottom Line: a Framework for Developing Indigenous Innovation. Wicazo Sa Review, 77+. 